\title{
BOARD DIVERSITY AND FINANCIAL PERFORMANCE IN INDONESIA
}

\author{
Deliana Azaria \\ Management Departement, University of Surabaya, Indonesia \\ Azariadeliana13@gmail.com \\ Werner R. Murhadi* \\ Management Departement, University of Surabaya, Indonesia \\ Werner@staff.ubaya.ac.id. \\ Bertha Silvia S. \\ Management Departement, University of Surabaya, Indonesia \\ Bertha7381@gmail.com
}

*Corresponding author

\begin{abstract}
Corporate governance has attracted many researchers to examine the relationship between board characteristics and financial performance. This study aims to determine the effect of board diversity, board size, and board independence on financial performance. This research is panel data with the number of observations reaching 1,355 years of observation. Financial performance is measured using accounting-based and market-based. It was found that the presence of female directors could not provide sound financial performance, even with a woman's prudence attitude would have an impact on decreasing the company's market value. The size of the board of directors does not affect financial performance, and the large size of the board of directors will have an impact on the decline in firm value. Independent directors are also not proven to be able to improve the company's financial performance; even the tendency of companies to carelessly fulfill the provisions of the rules regarding the existence of independent directors will bring a burden to the company so that it has an impact on the decline in company value.

Keywords: board diversity, board size, board independent, financial performance.

\section{INTRODUCTION}

Corporate governance has a significant impact on the economy because good governance can ensure returns to investors by minimizing the associated investment risks and contributing to company performance (Murhadi et al., 2018; Shleifer \& Vishny, 1997). The board of directors plays a fundamental role in strengthening corporate governance through an essential role in monitoring and advising on resource provision (Ntim et al., 2015). Corporate governance has attracted many studies to
\end{abstract}


examine the relationship between board characteristics and financial performance. The board of directors, an essential mechanism in a company, has responsibility for oversight and protecting the interests of the company's shareholders. These functions make the board of directors one of the essential internal corporate governance control mechanisms in an entity (Campbell \& Mínguez-Vera, 2008).

On a global scale, women's representation on boards of directors and management teams is still limited. External pressure on companies to include women on boards comes from social groups, shareholders, and policymakers. Gender diversity is considered a strategic corporate issue and affects corporate governance practices (Campbell \& Mínguez-Vera, 2008; Francoeur et al., 2008). The presence of women can increase the effectiveness of the board of directors. Gender diversity on the board of directors is a topic of increasing scientific and policy-making interest (Lagos Cortés et al., 2018). The representation of women at the top of the corporate hierarchy has an essential impact on business performance. Gender diversity itself can expand the range of experience and expertise and the human resources available to a team (Adams \& Ferreira, 2009). The privilege of women's participation on the board of directors of companies, especially in developing countries, can make a more substantial contribution to cognitive variation for improving business performance. (Palaniappan, 2017).

Gender diversity is positively related to business performance. Women with characteristics who are more careful and details will be considered able to reduce the aggressiveness of men on the board of directors. Gender diversity will impact companies that are more controlled and cautious in carrying out risky expansions. With more control of the company, the profitability performance is also getting better (Abdullah et al., 2016; Assenga et al., 2018; Kılıç \& Kuzey, 2019; Lagos Cortés et al., 2018). This more controlled company is also following the resource dependence theory; women on board can convince stakeholders about its diversity, increase its legitimacy, and connect with the external environment (Lückerath-Rovers, 2013). Meanwhile, there is a growing perception that women with soft and emotional characteristics can make surveillance ineffective. The dominance of men in the world of work creates a gender bias so that not many women can reach positions on the board of directors. The presence of women is not effective in improving company performance as measured by using ROA. The reasons are that first, the presence of women is only a complementary role in corporate governance. Second, the law regarding gender diversity is still minimal. Women are also considered to be emotional, aggressive, risk-averse, and insecure (Lagos Cortés et al., 2018)

This study also examines the effect of board size and board independence on financial performance. Small board size can coordinate and communicate better than a large board size because information flows more easily. Smaller board sizes also have the advantage of lower costs and faster decision-making processes. This smaller board size is more efficient in increasing financial performance (K1lı̧ \& Kuzey, 2019; Koji et al., 2020). However, another opinion states that with larger body sizes, there can be 
synergies and increased supervision to impact better performance (Assenga et al., 2018; Lagos Cortés et al., 2018).

An independent board is an independent and is not bound to shareholders or executives. With independent status, they will be more neutral (Bhagat \& Bolton, 2019; Lagos Cortés et al., 2018; Malik \& Makhdoom, 2016; Tricker, 2012) Supporters of agency theory argue that most independent boards can effectively monitor company executives to minimize agency costs (Fama \& Jensen, 1983; Jackling \& Johl, 2009). While different opinions state that even though it is called board independence, it is not fully independent in practice, so the existence of board independence does not contribute to performance. Board independence and oversight becomes ineffective (Assenga et al., 2018; Ferrer \& Banderlipe II, 2012; Haniffa \& Hudaib, 2006; Kılıç \& Kuzey, 2019). Consistent with Fulgence (2014) argues that some directors may not be completely independent in Tanzania because selecting and appointing an independent board is not entirely transparent.

From the explanation above, this research will examine gender diversity, the board size, and board independence on financial performance in Indonesia. This study also uses control variables in the form of Firm Size and Leverage. The larger the size of the company, the lower the company's financial performance. The larger the firm size, the greater the total assets of the company. However, some companies have significant assets but cannot use them to the maximum in generating profits. Significant total assets also indicate that many assets are unemployed so that the profit received is less than the maximum (Assenga et al., 2018; Lagos Cortés et al., 2018). The larger the firm size has a significantly positive effect on the return on assets. Large companies will receive more attention, so the board of directors and directors will work harder in conducting supervision and management activities. So the size of the company is expected to provide added value for increasing the company's financial performance (The effect of company size on profitability is because the larger the size of the company, the higher the total assets and operating income of the company and will increase profitability as measured by the company's ROA (Bhatt \& Bhattacharya, 2015; K1liç \& Kuzey, 2019). Leverage is measured as a percentage of the book value of total debt to total assets, determining the company's specific risk. That is, the higher the leverage, the closer the company is to bankruptcy risk. The level of bankruptcy costs is associated with a high level of debt. Thus, a negative association occurs between leverage and firm performance (Kılıç \& Kuzey, 2019; Lagos Cortés et al., 2018)

\section{RESEARCH METHODS}

This study is all non-financial companies listed on the Indonesia Stock Exchange (IDX). Measurement of financial performance as the dependent variable in this study is proxied using return on assets (ROA) and firm value (Tobin's Q). In Indonesia, the Board of directors whose function is to supervise management is better known as the Board of Commissioners. For the independent variable, gender diversity is measured by the percentage of women in the board of directors (woman), board size is measured by the number of boards of directors (Bsize), and board independence is measured by 
the percentage of independent directors in the board of directors (B_Ind). The control variable of firm size is measured by the natural logarithm of total assets (Fsize), while the debt ratio measures debt (Lev). The data used is panel data with multiple linear regression analysis techniques. The sample criteria used are companies listed on the Indonesia Stock Exchange for five consecutive years and have audited financial and annual reports, and all data is available as needed for all variables during the 20152019 period.

\section{RESULTS \& DISCUSSION}

This study uses 271 companies, with the number of observations reaching 1,355 years of observation. Multicollinearity test was conducted with the results in table 1, where there is no multicollinearity between variables.

\section{Table 1.}

Correlation Coefficient

\begin{tabular}{cccccc}
\hline & Woman & BSIZE & B_IND & FSIZE & LEV \\
\hline Woman & 1.000000 & -0.127456 & -0.025950 & -0.132954 & -0.022597 \\
BSIZE & -0.127456 & 1.000000 & -0.091527 & 0.480023 & 0.115402 \\
B_IND & -0.025950 & -0.091527 & 1.000000 & 0.084573 & 0.175411 \\
FSIZE & -0.132954 & 0.480023 & 0.084573 & 1.00000 & 0.283004 \\
LEV & -0.022597 & 0.115402 & 0.175411 & 0.283004 & 1.00000 \\
\hline
\end{tabular}

Tests on the Chow test are presented in table 2. The Chow test shows significant results in both models, so it is continued with the Haussman test.

Table 2.

Chow-Test

\begin{tabular}{lrrr}
\hline Effects Test & \multicolumn{1}{c}{ Statistic } & d.f. & Prob. \\
\hline Model 1 with ROA as dependent variable & & & \\
Cross-section F & 8.729871 & $(270,1079)$ & 0.0000 \\
Cross-section Chi-square & 1569.476511 & 270 & 0.0000 \\
Model 2 with Tobisn Q as dependent variable & & \\
Cross-section F & 20.549512 & $(270,1079)$ & 0.0000 \\
Cross-section Chi-square & 2459.559543 & 270 & 0.0000 \\
\hline
\end{tabular}

Journal of Entrepreneurship \& Business, Vol.2, No. 2. 
Table 3 shows the Haussman test results for both models, where all the results are significant, so the results to be interpreted are fixed effects models.

Table 3.

Haussman-Test

\begin{tabular}{lccc}
\hline Test Summary & Chi-Sq. Statistic & Chi-Sq. d.f. & Prob. \\
\hline $\begin{array}{l}\text { Model 1 with ROA as dependent variable } \\
\begin{array}{l}\text { Cross-section random } \\
\text { Model 2 with Tobisn Q as dependent variable }\end{array}\end{array}$ & 11.996130 & 5 & 0.0348 \\
\begin{tabular}{l} 
Cross-section random \\
\hline
\end{tabular} & 13.140046 & 5 & 0.0221 \\
\hline
\end{tabular}

In table 4, for the dependent variable ROA, it is found that diversity on the board or women in the board of directors does not affect the return on assets (ROA). This result is because women on the board of directors are considered ineffective in improving company performance. The first reason is that the existence of women is only a complementary role in governance. The second is if the law regarding the existence of gender in the directors is still minimal. Francoeur et al. (2008) confirmed that the presence of women in the business is explicitly only to improve company policies because women have an emotional, risk-averse, aggressive, and insecure nature.

Table 4.

The Result

\begin{tabular}{ccccc}
\hline Variable & \multicolumn{2}{c}{ ROA } & \multicolumn{2}{c}{ Tobins Q } \\
& Coefficient & t-Statistic & Coefficient & t-Statistic \\
\hline C & -0.162 & $-1.96^{* *}$ & 6.995 & $20.51^{* * *}$ \\
Woman & 0.000 & 0.13 & -0.208 & $-9.01^{* * *}$ \\
BSIZE & -0.000 & -0.12 & -0.008 & $-1.89 *$ \\
B.IND & -0.005 & $-1.81^{*}$ & -0.126 & $-3.36^{* * *}$ \\
FSIZE & 0.009 & $3.19^{* * *}$ & -0.187 & $-15.62^{* * *}$ \\
LEV & -0.126 & $-24.18^{* * *}$ & 0.382 & $11.09^{* * *}$ \\
Adjusted R-squared & 0.925879 & 0.952520 \\
F-statistic & 62.50366 & 99.77542 \\
Prob(F-statistic) & 0.00000 & 0.00000 \\
\hline
\end{tabular}

Note: $* * *$ significant at $\alpha 1 \%$; **significant at $\alpha 5 \%$; *significant at $\alpha 10 \%$;

In the second model, it was found that the results of women in the board of directors had a significant adverse effect on Tobin's Q (TQ). This negative effect is in line with research conducted by Ferreira (2010), which found that women on the board of directors have a negative influence on company performance when there are not enough qualified women for top management positions. Darmadi (2013) also found that the presence of women in directors has a negative effect; this is due to the condition 
of companies registered in Indonesia being family companies where most of the companies will be controlled by families. In addition, the presence of women in the composition of the directors is more likely to be related to family relationships compared to the actual competence possessed. Having women on the board allows for increased internal conflict due to different risks.

The size of the board of directors from table 3 is also found not to affect the return on assets (ROA). This result is because the board members lack skills and expertise, which causes the board of directors to be ineffective in supervising management. Thus, the size of the board of directors cannot guarantee financial performance. The board of directors' size in the company is not a determining factor that can improve company performance. Instead, it is seen how the Board of Directors works effectively. The second model found that the size of the board of directors had a non-significant negative effect on Tobin's Q (TQ). This result is because there are members of the board of directors who lack skills and expertise, causing ineffective management supervision. It can be concluded that the size of the board of directors is not a determining factor that can improve company performance but how effective the board of directors is in monitoring and supervising management which will have an impact on improving performance (Topal \& Dogan, 2014).

For the independent commissioner variable on ROA, significant negative results were found at the level of $10 \%$. This result means that the existence of an independent commissioner gives a negative result which means a decrease in ROA performance. This result can be understood by independent directors whose selection process is not carried out openly, which impacts the selection of independent directors who tend only to fulfill obligations. At the same time, the existence of an independent commissioner will incur costs for the company. This independent board has an impact on the company's burden of increasing so that performance decreases. The second model found that the independent commissioner has a significant negative effect on Tobin's Q. This study indicates that the independent commissioner has not managed management effectively, reducing company performance. Independent directors who do not have experience and knowledge of the company's objectives also impact the company's expenses which are increasing compared to the benefits derived from the existence of independent directors. This study is also supported by Bhagat \& Bolton (2019), who found that independent directors have a negative influence on company performance, this is because if a company has a small proportion of independent directors, it can carry out adequate supervision of management which causes company performance to increase.

Table 3 for the control variable company size shows that the results have a significant positive effect on ROA. A large company size makes companies gain economies of scale in operations so that costs are relatively cheaper than companies with smaller sizes (Gunawan et al., 2019). In addition, the larger the size of the company, the public will trust it more so that it is easier for the company to market the product. These results can affect the company's profitability; the more significant the company's size will significantly influence profitability and company value. In 
addition, a large company size can increase product differentiation, and lower production costs will improve company performance (Kulic and Kuzey, 2016). However, the company size variable was found to have a significant adverse effect on Tobin's Q. This negative effect is because if the company's size gets large, it will require tighter supervision while the smaller company size will be easier to grow to increase its value. In addition, investors assess that the larger the size of the company, the greater the risk faced by the company. Larger companies also tend to have many problems compared to small companies; this can decrease company performance, thus affecting investors' views on the company. (Bhat and Bhattacharya, 2015).

For the control variable, leverage was found to have a significant adverse effect on ROA. This negative effect can be explained if a company has a high level of debt; it will cause the debt burden to be paid to be higher so that the company is getting closer to the risk of bankruptcy Gunawan et al. (2019). Companies that use a debt proportion that is too high can cause the lender to carry out strict supervision of the company. This strict supervision has an impact that management is limited to carrying out company operational activities so that it has an impact on reducing company performance (K1lıç \& Kuzey, 2019; Moreno-Gómez et al., 2018; Sheikh \& Wang, 2013). However, in table 3, it is also found that the results of the leverage variable have a significant positive effect on Tobin's Q. This result can be interpreted if the higher the levels of leverage, the higher the value of Tobin's Q. Companies that use more significant debt mean that the company is confident in its ability to settle debt obligations. This argument follows the signaling theory, where the announcement of the company getting debt will be responded to by an increase in the company's stock price. It can be understood that a company that obtains debt means that in the eyes of creditors, the company has sufficient financial capacity to meet all obligations to creditors (Dwidjaja et al., 2017).

\section{CONCLUSION}

Based on the study results, it was found that the presence of female directors cannot provide sound financial performance; even a woman's prudence will have an impact on the decline in the company's market value. The size of the board of directors does not affect financial performance, and the large size of the board of directors will have an impact on the decline in firm value. Independent directors are also not proven to be able to improve the company's financial performance; even the tendency of companies to carelessly comply with the provisions of the rules regarding the existence of independent directors will bring a burden to the company so that it has an impact on decreasing the value of the company.

The results of this study have a theoretical implication that the existence of women who are expected to be able to improve company performance is not proven; even investors perceive it as a negative thing. Theoretically, the size of the board of directors will also increase the financial burden, causing financial performance not to be better. The existence of an independent commissioner, which theoretically would increase supervision, was found to be the opposite. This result has practical implications that 
the selection of women and independent directors is expected to be done openly so that investors know the capabilities of these women directors and independent directors. This study focuses on the individual characteristics of directors, namely gender and independent.

\section{REFERENCES}

Abdullah, S. N., Ismail, K. N. I. K., \& Nachum, L. (2016). Does having women on boards create value? The impact of societal perceptions and corporate governance in emerging markets. Strategic Management Journal, 37(3), 466-476.

Adams, R. B., \& Ferreira, D. (2009). Women in the boardroom and their impact on governance and performance. Journal of Financial Economics, 94(2), 291-309.

Assenga, M. P., Aly, D., \& Hussainey, K. (2018). The impact of board characteristics on the financial performance of Tanzanian firms. Corporate Governance: The International Journal of Business in Society, 18(6), 1089-1106. https://dx.doi.org/10.1108/CG-09-2016-0174

Bhagat, S., \& Bolton, B. (2019). Corporate governance and firm performance: The sequel. Journal of Corporate Finance, 58, 142-168. https://doi.org/10.1016/j.jcorpfin.2019.04.006

Bhatt, R. R., \& Bhattacharya, S. (2015). Board structure and firm performance in Indian IT firms. Journal of Advances in Management Research.

Campbell, K., \& Mínguez-Vera, A. (2008). Gender diversity in the boardroom and firm financial performance. Journal of Business Ethics, 83(3), 435-451.

Darmadi, S. (2013). Do women in top management affect firm performance? Evidence from Indonesia. Corporate Governance: The International Journal of Business in Society, 13(3), 288-403. https://doi.org/https://dx.doi.org/10.1108/CG-12-20100096

Dwidjaja, S. P., Murhadi, W. R., \& Utami, M. (2017). Factors Affecting the Capital Structure and Effect on Its Performance. 14th International Symposium on Management (INSYMA 2017), 1-10.

Fama, E. F., \& Jensen, M. C. (1983). Separation of ownership and control. The Journal of Law and Economics, 26(2), 301-325.

Ferreira, D. (2010). Board diversity. Corporate Governance: A Synthesis of Theory, Research, and Practice, 8, 225.

Ferrer, R. C., \& Banderlipe II, M. R. S. (2012). The influence of corporate board characteristics on firm performance of publicly listed property companies in the Philippines. Academy of Accounting \& Financial Studies Journal, 16(4).

Francoeur, C., Labelle, R., \& Sinclair-Desgagné, B. (2008). Gender diversity in corporate governance and top management. Journal of Business Ethics, 81(1), 8395.

Fulgence, S. E. (2014). Corporate governance in Tanzania. In Corporate governance (pp. 157-185). Springer.

Gunawan, C. C., Murhadi, W. R., \& Utami, M. (2019). A study on the effects of good corporate governance - gender diversity on the company performance | Atlantis

Journal of Entrepreneurship \& Business, Vol.2, No. 2. 
Press. Proceedings of the 16th International Symposium on Management (INSYMA 2019). https://doi.org/https://dx.doi.org/10.2991/insyma-19.2019.9

Haniffa, R., \& Hudaib, M. (2006). Corporate governance structure and performance of Malaysian listed companies. Journal of Business Finance \& Accounting, 33(7-8), 1034-1062.

Jackling, B., \& Johl, S. (2009). Board structure and firm performance: Evidence from India's top companies. Corporate Governance: An International Review, 17(4), 492-509.

Kılıç, M., \& Kuzey, C. (2019). The effect of corporate governance on carbon emission disclosures. International Journal of Climate Change Strategies and Management, 11(1), 35-53. https://dx.doi.org/10.1108/IJCCSM-07-2017-0144

Koji, K., Adhikary, B. K., \& Tram, L. (2020). Corporate Governance and Firm Performance: A Comparative Analysis between Listed Family and Non-Family Firms in Japan. Journal of Risk and Financial Management, 13(9), 215.

Lagos Cortés, D., Betancourt Ramírez, J., \& Gómez Betancourt, G. (2018). Relationship between corporate governance, family control and financial performance in colombian companies. Innovar, 28(69), 85-98.

Lückerath-Rovers, M. (2013). Women on boards and firm performance. Journal of Management \& Governance, 17(2), 491-509.

Malik, M. S., \& Makhdoom, D. D. (2016). Does corporate governance beget firm performance in fortune global 500 companies? Corporate Governance, 16(4), 747-764. https://dx.doi.org/10.1108/CG-12-2015-0156

Moreno-Gómez, J., Lafuente, E., \& Vaillant, Y. (2018). Gender diversity in the board, women's leadership and business performance. Gender in Management: An International Journal, 33(2), 104-122. https://doi.org/https://dx.doi.org/10.1108/GM-05-2017-0058

Murhadi, W. R., Tanugara, F., \& Sutejo, B. S. (2018). The influence of good corporate governance on financial distress. Proceedings of the 15th International Symposium on Management 2018). https://doi.org/https://dx.doi.org/10.2991/insyma-18.2018.19

Ntim, C. G., Lindop, S., Osei, K. A., \& Thomas, D. A. (2015). Executive compensation, corporate governance and corporate performance: A simultaneous equation approach. Managerial and Decision Economics, 36(2), 67-96.

Palaniappan, G. (2017). Determinants of corporate financial performance relating to board characteristics of corporate governance in Indian manufacturing industry. European Journal of Management and Business Economics, 26(1), 67-85. https://dx.doi.org/10.1108/EJMBE-07-2017-005

Sheikh, N. A., \& Wang, Z. (2013). The impact of capital structure on performance: An empirical study of non-financial listed firms in Pakistan. International Journal of Commerce and Management, 23(4), 354-368. https://doi.org/https://dx.doi.org/10.1108/IJCoMA-11-2011-0034

Shleifer, A., \& Vishny, R. W. (1997). A survey of corporate governance. The Journal of Finance, 52(2), 737-783.

Journal of Entrepreneurship \& Business, Vol.2, No. 2. 
Topal, Y., \& Dogan, M. (2014). Impact of board size on financial performance: The case of BIST manufacturing industry. International Journal of Business Management and Economic Research, 5(4), 74-79.

Tricker, R. I. (2012). The cultural dependence of corporate governance. Keeping Good Companies, 64(1), 27-31.

Journal of Entrepreneurship \& Business, Vol.2, No. 2. 